\title{
MEASUREMENT AND CHARACTERIZATION OF DUST- FALL SAMPLES FROM MPUMALANGA PROVINCE, SOUTH AFRICA
}

\author{
MAPHUTI G. KWATA \& SHADUNG J. MOJA \\ Council for Geosciences, South Africa
}

\begin{abstract}
Exposure of asbestos dust comes from several sources that include mine dumps, unpaved road made of asbestos materials, blasting, crushing, grinding and milling activities, as well as spillages from trucks carrying the asbestos materials. The threat to human health is exacerbated by wind blowing over uncovered asbestos dust, making it airborne and inhaled by nearby local communities. The aim of this case study is to measure the dust-fall rates, characterize the dust and determine the metal levels in the resulting filtrate solutions within the Mpumalanga study area. The standard method for collection and analysis of dust-fall rates adopted by the American Standard Test Method (ASTM D 1739, 1970) and the South African National Dust Control Regulations (NDC R 827, 2013) was used. Filtrate solutions generated after filtering the collected falling dust were analyzed with Inductively Coupled Plasma-Mass Spectrometry (ICP-MS) to determine the levels of some trace metals. Dust samples were characterized with a Scanning Electron Microscopy-Energy Dispersive Spectrometry (SEM-EDS) to determine the morphology such as shape, size, length and width of asbestos fibers. Dust-fall rates measured from January to June 2016 were all below the residential standard limit of $600 \mathrm{mg} / \mathrm{m}^{2} /$ day at all five sampling sites. Site E was the highest with $478 \mathrm{mg} / \mathrm{m}^{2} /$ day measured in May 2016, possibly due to its close proximity to the asbestos mine dump. All trace metals of interest (manganese (Mn), iron $(\mathrm{Fe})$, nickel $(\mathrm{Ni})$, cadmium $(\mathrm{Cd})$ and lead $(\mathrm{Pb})$ ) exceeded the local and international standard limits. SEM-EDS results confirm the dominance of silicates minerals that include the serpentine $\left(\mathrm{Mg}_{3}(\mathrm{OH})_{4}\left(\mathrm{Si}_{3} \mathrm{O}_{5}\right)\right.$, amphibole $\left(\mathrm{NaCa}_{2}(\mathrm{Mg}, \mathrm{Fe}, \mathrm{Al})_{5}(\mathrm{Al}, \mathrm{Si})_{8} \mathrm{O}_{22}(\mathrm{OH})_{2}\right.$, quartz $\left(\mathrm{SiO}_{2}\right)$, plagioclase $\left(\mathrm{NaAlSi}_{3} \mathrm{O}\right)$, kaolinite $\left(\mathrm{Al}_{2} \mathrm{Si}_{2} \mathrm{O}_{5}(\mathrm{OH})_{4} \mathrm{Mg}, \mathrm{Fe}^{++5} \mathrm{Al}\left(\mathrm{Si}_{3} \mathrm{Al}\right) \mathrm{O}_{10}(\mathrm{OH})_{8}\right.$, feldspar (KAISQ $\left.\mathrm{O}_{8}\right)$ and mica $\left(\mathrm{KAI}_{2}\left(\mathrm{Si}_{3} \mathrm{Al}\right)_{10}\right)(\mathrm{OH})_{2}$. The presence of poisonous metals and asbestos fibers could have negative health impacts to the exposed individuals.

Keywords: asbestos mining, asbestos dust, dust fall rates, mine dumps, NDC R 827-2013, minerals, ASTM D 1739-1970, SEM-EDS, ICP-MS.
\end{abstract}

\section{INTRODUCTION}

Asbestos mining has left behind major environmental and health challenges. Wind blowing across the old and abandoned mine dumps transport dust to nearby communities. Asbestos is one of the oldest mineral mined in South Africa (Hart [1]). The risk of being exposed to asbestos dust is increased by the close proximity of human settlements to areas where asbestos minerals were mined and milled (Muculloch [2]). Asbestos materials were used by the rich and royals in the past to preserve the ashes after cremation (Abratt et al. [3]). Inhalation of asbestos dust or fibers is known to cause lung diseases such as asbestosis (scarring of the lungs), lung cancer and mesothelioma (a malignant and fatal tumor that grows on the lining of the lung) (Felix et al. [4]). The purpose of this study is to measure dust fall rates and characterize the resulting dust and filtrate solution samples collected within residential areas that are close to un-rehabilitated mine dumps around the Mpumalanga Province with the intention of assessing the asbestos pollution levels. 


\section{EXPERIMENTAL DESIGN}

\subsection{Study area, geology and sampling points}

The study area is situated in Mpumalanga Province around residential areas that are near unrehabilitated asbestos mine dumps within Mbombela (previously known as Nelspruit), Malelane and Carolina towns as shown in Fig. 1. Mbombela is the capital city of the Mpumalanga Province and is located centrally, but on the eastern direction. The province is known to have pine tree and escarpment and mountainous. Dust fall dust samples were collected around five local communities and the sampling sites were within $5 \mathrm{~km}$ of the nearby old and abandoned asbestos mine dumps. Asbestos minerals are products of metamorphic rock such bended iron formation and occur in narrow veins as cross fiber extending from wall to wall or as slip fiber "needle like" parallel to the vein walls. The asbestos mass fiber is an aggregate of various oriented fibers and differ in structure, chemistry and physical properties. Fig. 2 shows the geological make-up within the province and contains Komatipoort Group and Transvaal SuperGroup. The common rocks are sandstones, shale, murchison, greenstone belt and intrusive granite, etc. Komatities often display spectacular textures of skeletal crystals (known as spinifex textures) which branch out like fern leaves. The textures and the chemical make-up of the rocks can be deduced komatities lavas crystallized exceptionally rapidly from very hot and probably water-rich molten magma (Ehlers and Vorster [5]).

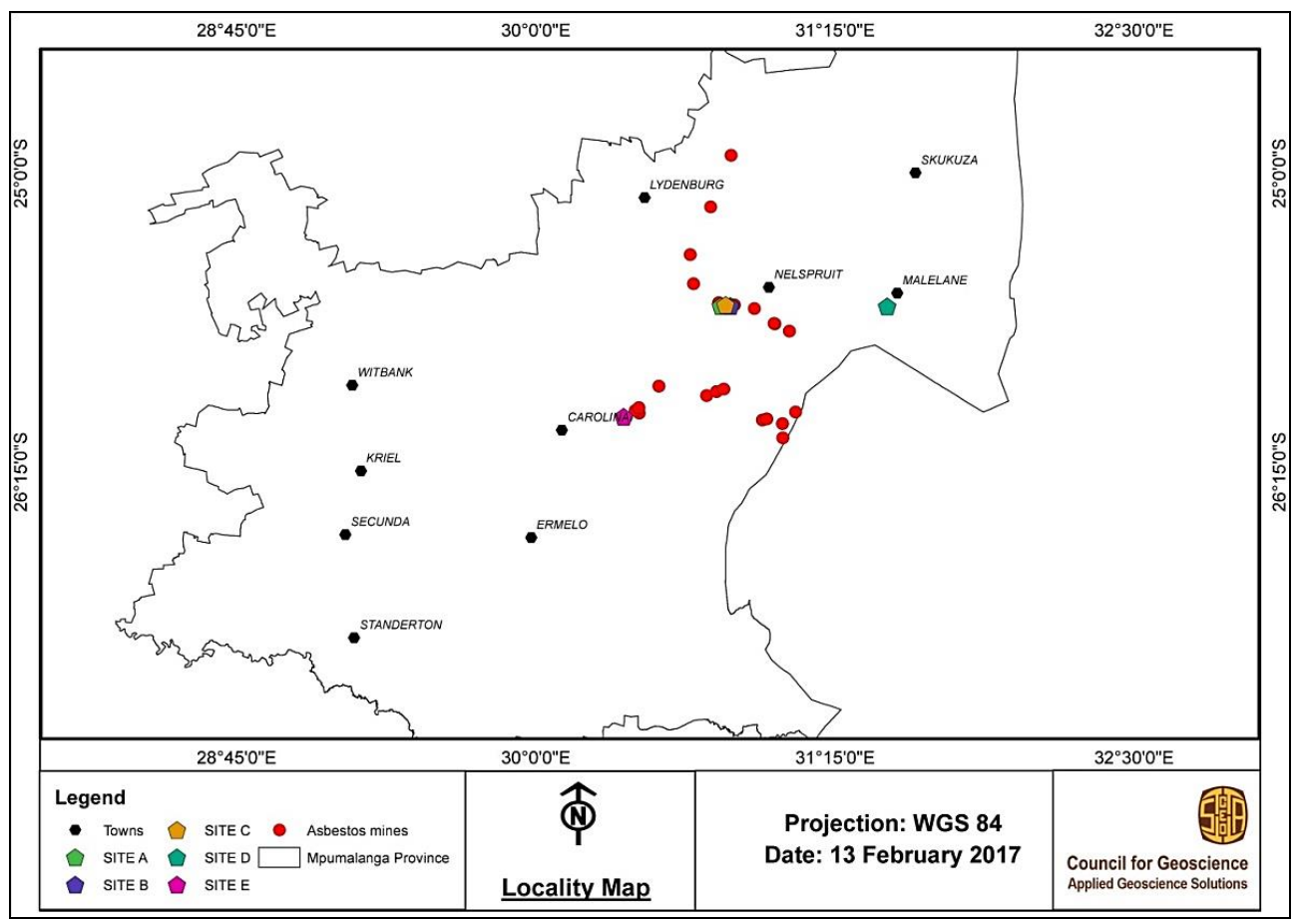

Figure 1: A map showing the location of asbestos mine dumps and five sampling points in Mpumalanga Province. 


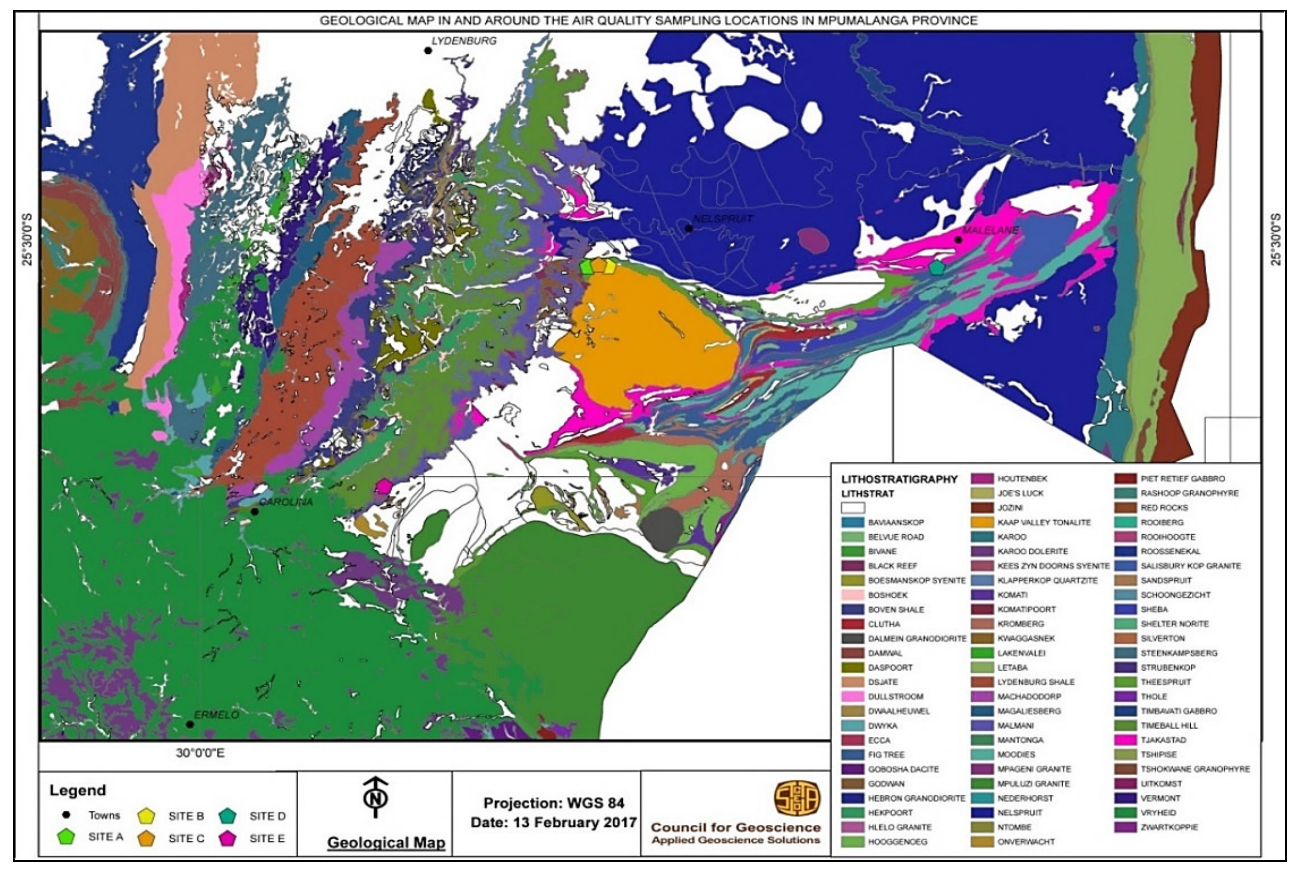

Figure 2: A map showing the geology of Mpumalanga Province.

\subsection{Samples collection method}

Dust fall samples were collected from January 2016 to June 2016 at sites that are within the local communities situated near old and abandoned asbestos mine dumps. Individual units were installed within the yards of five farm houses. An individual dust fall collection unit is made of a single $5.0 \mathrm{~L}$ cylindrical bucket half filled with deionized water placed on a $2.0 \mathrm{~m}$ high stand with a bird ring on top (Fig. 3). The units are exposed on identified sites for a period of $30.0 \pm 33.0$ days before being replaced with clean ones. The exposed units containing dust fall samples are transferred to the laboratory and filtered with a Buchner filtration system. After filtration, dried dust samples on filter papers are placed in the desiccator to allow mass to stabilize before being weighed to determine the exact amount of dust that settled using gravimetric calculations.

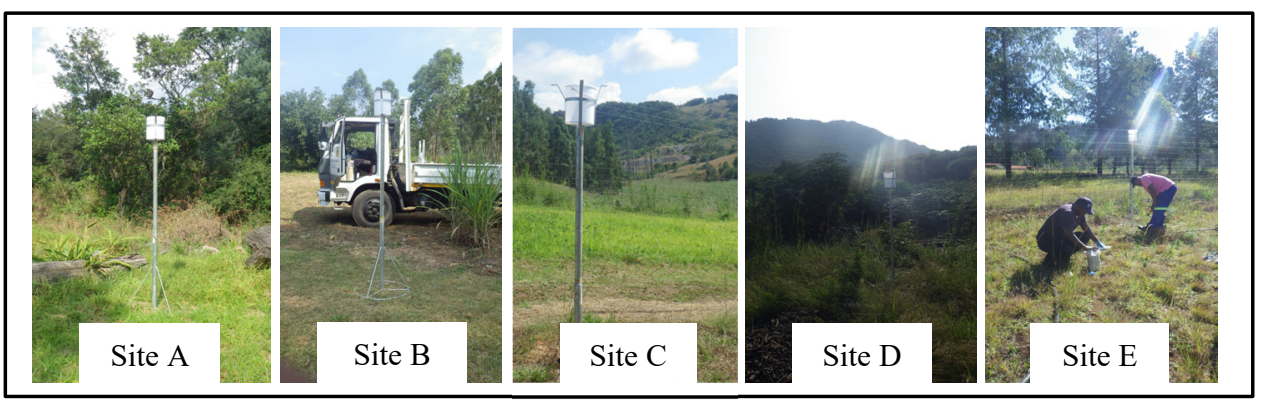

Figure 3: Dust-fall sample collectors installed at five sites. 


\subsection{Sample preparation and analyses methods}

The mass concentration expressed as dust-fall rate ( $\mathrm{D}$ in $\mathrm{mg} / \mathrm{m}^{2} /$ day) was determined by calculating the total weight mass $\left(\mathrm{W}_{\mathrm{m}}\right.$ in $\left.\mathrm{mg}\right)$ divided by the cross-section area of the dust-fall bucket diameter (A in $\mathrm{m}^{2}$ ) and multiplied by the number of days (30 days) on site as shown below:

$$
D=\frac{W_{m}}{A \times \text { number of days }} .
$$

Filtered dust samples (stored in transparent closed plastic containers as shown in Fig. 4) were studied further using an X-Ray Diffraction (XRD) analytical technique to evaluate the mineralogical composition. SEM-EDS was used to determine morphology which includes the size, shape and types of asbestos groups detected on the filtered dust samples (Perkins and Harvey [6]). Both instruments were conditioned according to the CGS Mineralogy Laboratory Methods (Atanasova [7]). All specimens for SEM-EDS were homogenized by light grinding by hand in agate mortar. The powder subsamples were then pressed into plastic holders preparing them to be analyzed as whole rock in a BRUKER D8 ADVANCE instrument. It has a $2.2 \mathrm{~kW} \mathrm{Cu}$ long fine focus tube $(\mathrm{Cu} \mathrm{K \alpha}, \lambda=1.54060)$ and 90 position sample changer. The system is equipped with LynxEye detector with $3.7^{\circ}$ active area. Samples are scanned from 2 to 70.2 at a speed of $0.02-2$ steps size $/ 3 \mathrm{sec}$, and generator settings of $40 \mathrm{kV}$ and $40 \mathrm{~mA}$. Phase identification is based on BRUKER DIFFRACPlus EVA evaluation program. The ICDD Inorganic/Organic Data base is used for phase search. Filtrate solutions samples (in plastic containers with white caps, Fig. 4) were analyzed using ICP-MS to determine the trace metals pollution levels.

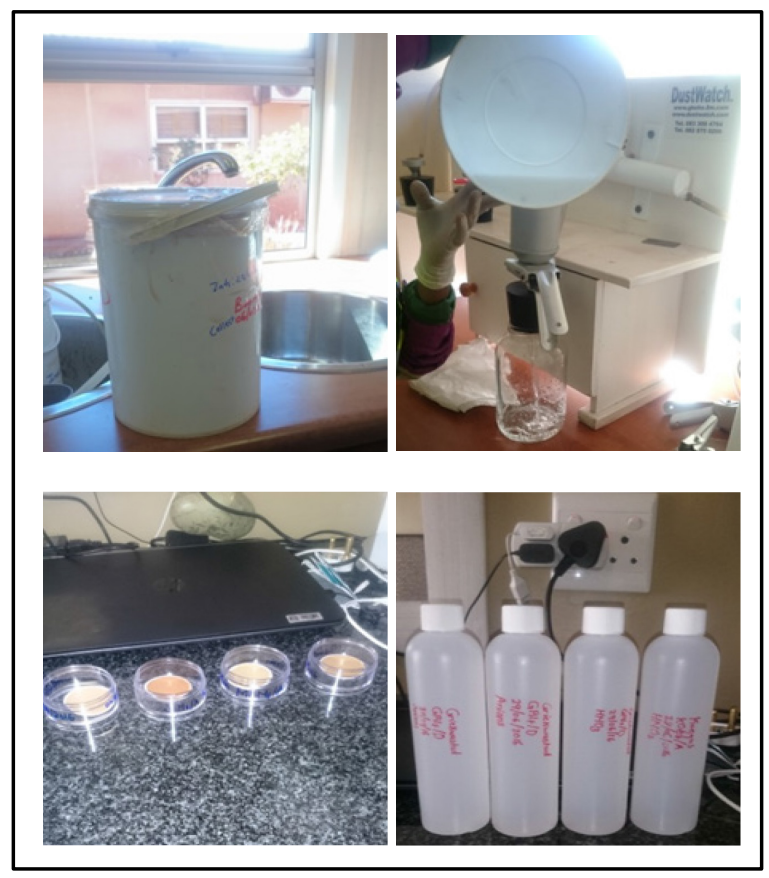

Figure 4: Dust samples filtration process in the laboratory. 


\section{RESULTS AND DISCUSSIONS}

3.1 Dust-fall rates results

Table 1: Dust fall rates results from January to June 2016.

\begin{tabular}{c|c|c|c|c|c|c}
\hline $\begin{array}{c}\text { Sampling } \\
\text { sites }\end{array}$ & Jan-16 & Feb-16 & Mar-16 & Apr-16 & May-16 & Jun-16 \\
\hline Site A & 89 & 37 & 43 & 22 & 39 & 59 \\
\hline Site B & 32 & 43 & 74 & 37 & 54 & 39 \\
\hline Site C & 43 & 91 & 77 & 39 & 102 & 76 \\
\hline Site D & 22 & 50 & 67 & 106 & 478 & 126 \\
\hline Site E & 52 & 57 & 26 & 32 & 37 & 44 \\
\hline
\end{tabular}

All the dust-fall rates are below the local residential limit of $600 \mathrm{mg} / \mathrm{m}^{2} /$ day from all the sites (NDC R 827, 2013) (NDCR [8]). Site D measured the most dust of $478 \mathrm{mg} / \mathrm{m}^{2} /$ day in May 2016, followed $126 \mathrm{mg} / \mathrm{m}^{2} /$ day in June and $106 \mathrm{mg} / \mathrm{m}^{2} /$ day in April at the same site, and $102 \mathrm{mg} / \mathrm{m}^{2} /$ day at site $\mathrm{C}$ in May 2016. The lowest dust fall rates were detected at Site A in April 2016 and Site D in January with $22 \mathrm{mg} / \mathrm{m}^{2} /$ day.

\subsection{Metal filtrate results from January to May 2016.}

The concentration levels of essential metals $(\mathrm{Mn}, \mathrm{Fe}, \mathrm{Ni}$ and $\mathrm{Cu}$ ) and non-essential metals $(\mathrm{Cr}, \mathrm{Cd}$ and $\mathrm{Pb})$ in filtrate solution samples, together with relevant standard levels are shown in Table 2. The data measured from January to February represent the summer season, while the period from April to May represent the winter period.

Table 2: $\quad$ Metal concentration $(\mathrm{mg} / \mathrm{L})$ ranges for filtrate results ranges from January until May 2016.

\begin{tabular}{c|c|c|c|c|c|c|c}
\hline $\begin{array}{c}\text { Sampling } \\
\text { points }\end{array}$ & $\begin{array}{c}\text { Mn } \\
\text { USEPA=0.05 } \\
\text { WHO=0.1 } \\
\text { RSA=0.05 }\end{array}$ & $\begin{array}{c}\text { Fe } \\
\text { RSA=0.1 }\end{array}$ & $\begin{array}{c}\text { Ni } \\
\text { USEPA=0.07 } \\
\text { WHO=0.07 } \\
\mathbf{R S A = 0 . 0 2}\end{array}$ & $\begin{array}{c}\text { Cu } \\
\text { RSA=1 }\end{array}$ & $\begin{array}{c}\text { Cr } \\
\text { WHO=0.05 } \\
\text { RSA=5 }\end{array}$ & $\begin{array}{c}\text { Cd } \\
\text { USEPA=0.003 } \\
\text { WHO=0.003 } \\
\text { RSA=5 }\end{array}$ & $\begin{array}{c}\text { Pb } \\
\text { USEPA } \\
=\mathbf{0 . 0 5} \\
\text { WHO=0.01 }\end{array}$ \\
\hline Site A & $<0.5-15.4$ & $<23.9-141.9$ & $<0.04-34.1$ & $<0.20-204$ & $<0.6-1.9$ & $1.1-17.2$ & $5.2-25.7$ \\
\hline Site B & $<0.5-128$ & $<23.9-38.8$ & $<0.04-2.8$ & $<0.20-1.4$ & $<0.6$ & $<0.06-1.2$ & $<0.06-45.3$ \\
\hline Site C & $2.9-48.5$ & $<23.9-297.4$ & $<0.04-8.4$ & $<0.20-3.3$ & $<0.6-3.3$ & $1-17.1$ & $1.9-25.7$ \\
\hline Site D & $1.7-57.9$ & $<23.9-57.9$ & $<0.04-5$ & $<0.20-14$ & $<0.01-2.3$ & $<0.06-1.1$ & $7.1-17$ \\
\hline Site E & $<0.5-99.3$ & $<23.9-652.8$ & $<0.04-8.9$ & $<0.20-20$ & $<0.01-4.7$ & $<0.06-17.7$ & $7.9-1204.7$ \\
\hline
\end{tabular}


Seasonal levels for essential metals are discussed per site, starting with site A in Mpumalanga, manganese (Mn) metal concentration is $<0.5 \mathrm{mg} / \mathrm{L}$ in summer and in the range of $<0.5-15.4 \mathrm{mg} / \mathrm{L}$ in autumn, which were all exceeded (RSA [9]) and (USEPA [10]) limits of $0.05 \mathrm{mg} / \mathrm{L}$ and (WHO [11]) limit of $0.1 \mathrm{mg} / \mathrm{L}$. Iron (Fe) metal concentration ranged $<23.9-44.2 \mathrm{mg} / \mathrm{L}$ in summer and ranged $<23.9-141.9 \mathrm{mg} / \mathrm{L}$ in autumn, which all exceeded the RSA (1995) limit of $0.1 \mathrm{mg} / \mathrm{L}$. Nickel (Ni) metal concentration is $<0.04 \mathrm{mg} / \mathrm{L}$ in summer and ranged 2.7-34.1 mg/L in autumn, all of which exceeded WHO (2011) and USEPA (2003) limits of $0.07 \mathrm{mg} / \mathrm{L}$ and RSA (1995) limit of $0.02 \mathrm{mg} / \mathrm{L}$. Copper $(\mathrm{Cu})$ metal concentration is $<0.20 \mathrm{mg} / \mathrm{L}$ in summer and ranged $<0.20-2.4 \mathrm{mg} / \mathrm{L}$ in autumn, which were all exceeded RSA limit of $1 \mathrm{mg} / \mathrm{L}$. The non-essential metal concentration for cadmium $(\mathrm{Cd})$ exceeded the limits of USEPA (2003) and WHO (2011) of $0.03 \mathrm{mg} / \mathrm{L}$ and are below RSA (1995) limit of $5 \mathrm{mg} / \mathrm{L}$ with summer $2.5 \mathrm{mg} / \mathrm{L}$ and ranged from $1.1-17.2 \mathrm{mg} / \mathrm{L}$ in autumn. According to the USEPA (2003) limit of $0.05 \mathrm{mg} / \mathrm{L}$ and WHO (2011) limit of $0.01 \mathrm{mg} / \mathrm{L}$, the lead $(\mathrm{Pb})$ metal concentration is $7.8 \mathrm{mg} / \mathrm{L}$ in summer and ranged from $5.2-15.8 \mathrm{mg} / \mathrm{L}$ in autumn. Chromium (Cr) metal concentration is $1.1 \mathrm{mg} / \mathrm{L}$ in summer and ranged from $<0.6-1.9 \mathrm{mg} / \mathrm{L}$ in autumn, which all exceeded the limits of WHO (2011) of $0.05 \mathrm{mg} / \mathrm{L}$, USEPA (2003) of $0.03 \mathrm{mg} / \mathrm{L}$ and RSA (1995) limit of $5 \mathrm{mg} / \mathrm{L}$.

Table 3: Metals concentration (mg/L) for filtrate results from January to May 2016.

\begin{tabular}{|c|c|c|c|c|c|c|c|}
\hline $\begin{array}{l}\text { Sampling } \\
\text { points } \\
\text { and dates }\end{array}$ & $\begin{array}{c}\text { Mn } \\
\text { USEPA }=0.05 \\
\text { WHO }=0.1 \\
\text { RSA }=0.05\end{array}$ & $\begin{array}{c}\mathrm{Fe} \\
\mathrm{RSA}=\mathbf{0 . 1}\end{array}$ & $\begin{array}{c}\text { Ni } \\
\text { WHO=0.07 } \\
\text { USEPA }=0.07 \\
\text { RSA }=\mathbf{0 . 0 2}\end{array}$ & $\begin{array}{c}\mathrm{Cu} \\
\mathrm{RSA}=1\end{array}$ & $\begin{array}{c}\text { Cr } \\
\text { WHO }=0.05 \\
\text { RSA }=5\end{array}$ & $\begin{array}{c}\text { Cd } \\
\text { WHO }=0.005 \\
\text { USEPA }=0.003 \\
\text { RSA }=5\end{array}$ & $\begin{array}{c}\mathrm{Pb} \\
\mathrm{USEPA}=\mathbf{0 . 0 5} \\
\mathrm{WHO}=\mathbf{0 . 0 1}\end{array}$ \\
\hline
\end{tabular}

Jan-16

\begin{tabular}{l|c|c|c|c|c|c|c}
\hline Site A & No data & No data & No data & No data & No data & No data & No data \\
\hline Site B & No data & No data & No data & No data & No data & No data & No data \\
\hline Site C & No data & No data & No data & No data & No data & No data & No data \\
\hline Site D & No data & No data & No data & No data & No data & No data & No data \\
\hline Site E & No data & No data & No data & No data & No data & No data & No data \\
\hline
\end{tabular}

Feb-16

\begin{tabular}{c|c|c|c|c|c|c|c}
\hline Site A & $<0.5$ & $<23.9$ & $<0.04$ & $<0.20$ & $<0.6$ & 2.5 & 7.8 \\
\hline Site B & 27.2 & 38.8 & 2.8 & 1.4 & $<0.6$ & 1.2 & 45.3 \\
\hline Site C & 5.6 & 36.6 & 1.2 & 1.9 & 3.3 & 1 & 1.9 \\
\hline Site D & 5.9 & 57.9 & 5 & 14 & 2.3 & 1.1 & 7.1 \\
\hline Site E & 76.5 & 204.2 & 14.3 & 6.1 & 4.7 & 1.1 & 1204.7 \\
\hline
\end{tabular}

Mar-16

\begin{tabular}{c|c|c|c|c|c|c|c}
\hline Site A & $<0.5$ & $<23.9$ & 34.1 & $<0.20$ & $<0.6$ & 1.1 & 5.2 \\
\hline Site B & $<0.5$ & $<23.9$ & $<0.04$ & $<0.20$ & $<0.6$ & 1.1 & 2.8 \\
\hline Site C & 2.9 & 297.4 & $<0.04$ & $<0.20$ & $<0.6$ & 1.1 & 25.7 \\
\hline Site D & 36.3 & $<23.9$ & $<0.04$ & $<0.20$ & $<0.6$ & 1.1 & 9.6 \\
\hline Site E & $<0.5$ & $<23.9$ & $<0.04$ & $<0.20$ & $<0.6$ & 1.1 & 7.9 \\
\hline
\end{tabular}


Table 3: Continued.

\begin{tabular}{c|c|c|c|c|c|c|c}
\hline \multicolumn{7}{c}{ Apr-16 } \\
\hline Site A & 15.4 & 141.9 & 2.7 & 2.4 & 1.9 & 17.2 & 15.8 \\
\hline Site B & 64.4 & 44.2 & $<0.04$ & $<0.20$ & $<0.01$ & $<0.06$ & 15.4 \\
\hline Site C & 48.5 & 181.8 & 8.4 & 3.3 & 2 & 17.1 & 15.6 \\
\hline Site D & 1.7 & $<23.9$ & $<0.04$ & $<0.20$ & $<0.01$ & $<0.06$ & 17 \\
\hline Site E & 99.3 & 652.8 & 8.9 & 20 & 2.6 & 17.7 & 15.7 \\
\hline \multicolumn{7}{|c|}{ May-16 } \\
\hline Site A & No data & No data & No data & No data & No data & No data & No data \\
\hline Site B & 128 & $<23.9$ & $<0.04$ & $<0.20$ & $<0.01$ & $<0.06$ & 15.2 \\
\hline Site C & 11 & $<23.9$ & $<0.04$ & 2 & $<0.01$ & $<0.06$ & 15.2 \\
\hline Site D & No data & No data & No data & No data & No data & No data & No data \\
\hline Site E & 57.6 & 80.1 & $<0.04$ & $<0.20$ & $<0.01$ & $<0.06$ & 15.3 \\
\hline
\end{tabular}

Note: Summer (Feb), Autumn (Mar-May).

Site B metal concentration of manganese $(\mathrm{Mn})$ is $27.2 \mathrm{mg} / \mathrm{L}$ in summer and ranged from $<0.5-128 \mathrm{mg} / \mathrm{L}$ in autumn, were all exceeded limits of USEPA (2003) and RSA (1995) of $0.05 \mathrm{mg} / \mathrm{L}$ and WHO (2011) limit of $0.1 \mathrm{mg} / \mathrm{L}$. Iron (Fe) metal concentration is $38.8 \mathrm{mg} / \mathrm{L}$ in summer and ranged from $<23.9-44.2 \mathrm{mg} / \mathrm{L}$ in autumn, which all exceeded RSA (1995) limit of $0.1 \mathrm{mg} / \mathrm{L}$. Nickel (Ni) is $<0.04 \mathrm{mg} / \mathrm{L}$ in summer and $<0.04 \mathrm{mg} / \mathrm{L}$ in autumn, all of which exceeded WHO (2011) and USEPA (2003) limits of $0.07 \mathrm{mg} / \mathrm{L}$ and RSA (1995) limit of $0.02 \mathrm{mg} / \mathrm{L}$. Copper $(\mathrm{Cu})$ metal concentration is $<0.20 \mathrm{mg} / \mathrm{L}$ in summer and ranged from $<0.20-<0.20 \mathrm{mg} / \mathrm{L}$ in autumn, which were all within RSA (1995) limit of $1 \mathrm{mg} / \mathrm{L}$. The non-essential metal concentration of cadmium (Cd) exceeded the limits of USEPA (2003) and WHO (2011) of $0.003 \mathrm{mg} / \mathrm{L}$ but below RSA (1995) limit of $5 \mathrm{mg} / \mathrm{L}$ in summer with 2.5 $\mathrm{mg} / \mathrm{L}$ and ranging from $<0.06-1.1 \mathrm{mg} / \mathrm{L}$ in autumn. According to USEPA (2003) limit of $0.05 \mathrm{mg} / \mathrm{L}$ and WHO (2011) limit of $0.01 \mathrm{mg} / \mathrm{L}$ exceeded the lead $(\mathrm{Pb})$ metal concentration is $45.3 \mathrm{mg} / \mathrm{L}$ in summer and $2.8-15.4 \mathrm{mg} / \mathrm{L}$ in autumn. Chromium $(\mathrm{Cr})$ metal concentration is $<0.6 \mathrm{mg} / \mathrm{L}$ in summer and ranged from $<0.01-<0.6 \mathrm{mg} / \mathrm{L}$ in autumn, which were below the limits of WHO (2011) of $0.005 \mathrm{mg} / \mathrm{L}$ and USEPA (2003) of $0.003 \mathrm{mg} / \mathrm{L}$ and RSA (1995) limit of $5 \mathrm{mg} / \mathrm{L}$.

Site C manganese $(\mathrm{Mn})$ metal concentration is $5.6 \mathrm{mg} / \mathrm{L}$ in summer and ranged from 2.9-48.5 mg/L in autumn, which were all exceeded USEPA (2003) and RSA (1995) limits of $0.05 \mathrm{mg} / \mathrm{L}$ and WHO (2011) limit of $0.1 \mathrm{mg} / \mathrm{L}$. Iron (Fe) metal concentration is $36.6 \mathrm{mg} / \mathrm{L}$ in summer and ranged from $<23.9-297.4 \mathrm{mg} / \mathrm{L}$ in autumn exceeded the RSA (1995) limit of $0.1 \mathrm{mg} / \mathrm{L}$. Nickel (Ni) is $1.2 \mathrm{mg} / \mathrm{L}$ in summer and ranged from $<0.04-8.4 \mathrm{mg} / \mathrm{L}$ in autumn, which were all exceeded USEPA (2003) and WHO (2011) limits of $0.07 \mathrm{mg} / \mathrm{L}$ and RSA (1995) limit of $0.02 \mathrm{mg} / \mathrm{L}$. Copper $(\mathrm{Cu})$ metal concentration is $1.9 \mathrm{mg} / \mathrm{L}$ in summer and ranged from $<0.20-3.3 \mathrm{mg} / \mathrm{L}$ in autumn exceeded RSA (1995) limit of $1 \mathrm{mg} / \mathrm{L}$. The non-essential metal concentration for cadmium $(\mathrm{Cd})$ with summer is $1 \mathrm{mg} / \mathrm{L}$ and ranging from $<0.06-17.1 \mathrm{mg} / \mathrm{L}$ in autumn, which were all exceeded the WHO (2011) and USEPA (2003) limits of $0.03 \mathrm{mg} / \mathrm{L}$, but below RSA (1995) limit of $5 \mathrm{mg} / \mathrm{L}$. Lead $(\mathrm{Pb})$ metal concentration is $1.9 \mathrm{mg} / \mathrm{L}$ in summer and ranged from $2.8-15.6 \mathrm{mg} / \mathrm{L}$ in autumn exceeded the USEPA (2003) limit of 0.05 and WHO (2011) limit of $0.01 \mathrm{mg} / \mathrm{L}$. Chromium (Cr) metal 
concentration is $3.3 \mathrm{mg} / \mathrm{L}$ in summer and ranged from $<0.01-2 \mathrm{mg} / \mathrm{L}$ in autumn which were all exceeded limits of USEPA (2003) of $0.003 \mathrm{mg} / \mathrm{L}$, WHO (2011) of $0.05 \mathrm{mg} / \mathrm{L}$ and RSA (1995) limit of $5 \mathrm{mg} / \mathrm{L}$.

Site D manganese (Mn) metal concentration is $5.9 \mathrm{mg} / \mathrm{L}$ in summer and ranged from $1.7-36.3 \mathrm{mg} / \mathrm{L}$ in autumn, which were all exceeded USEPA (2003) and RSA (1995) limits of $0.05 \mathrm{mg} / \mathrm{L}$ and WHO (2011) limit of $0.1 \mathrm{mg} / \mathrm{L}$. Iron $(\mathrm{Fe})$ metal concentration in summer is $57.9 \mathrm{mg} / \mathrm{L}$ and ranged from $<23.9-652.8 \mathrm{mg} / \mathrm{L}$ which were all exceeded the limit of RSA (1995) of $0.1 \mathrm{mg} / \mathrm{L}$. Nickel (Ni) metal concentration is $5 \mathrm{mg} / \mathrm{L}$ in summer and ranged from $<0.04-0.04 \mathrm{mg} / \mathrm{L}$ in autumn which were all exceeded USEPA (2003) and WHO (2011) limits of $0.07 \mathrm{mg} / \mathrm{L}$ and RSA (1995) limit of $0.02 \mathrm{mg} / \mathrm{L}$. Copper $(\mathrm{Cu})$ metal concentration is $6.1 \mathrm{mg} / \mathrm{L}$ in summer and ranged from $<0.20-<0.20 \mathrm{mg} / \mathrm{L}$ in autumn, which were all exceeded RSA (1995) limit of $1 \mathrm{mg} / \mathrm{L}$ except in autumn. The non-essential metal concentration for cadmium $(\mathrm{Cd})$ is $1.1 \mathrm{mg} / \mathrm{L}$ in summer and $<0.60-1.1 \mathrm{mg} / \mathrm{L}$ in autumn, which were all exceeded USEPA (2003) and WHO (2011) limits of $0.003 \mathrm{mg} / \mathrm{L}$ and RSA (1995) limit of $5 \mathrm{mg} / \mathrm{L}$. The lead $(\mathrm{Pb})$ is $7.1 \mathrm{mg} / \mathrm{L}$ in summer and ranged from $9.6-17 \mathrm{mg} / \mathrm{L}$ in autumn, which were all exceeded USEPA (2003) limit of $0.05 \mathrm{mg} / \mathrm{L}$ and WHO (2011) of $0.01 \mathrm{mg} / \mathrm{L}$. Chromium $(\mathrm{Cr})$ metal concentration is $<0.6 \mathrm{mg} / \mathrm{L}$ in summer and ranged from $<0.01-<0.6 \mathrm{mg} / \mathrm{L}$ in autumn which were all exceeded the limit of WHO (2011) of $0.05 \mathrm{mg} / \mathrm{L}$, USPEA (2003) of $0.003 \mathrm{mg} / \mathrm{L}$ and RSA (1995) limit of $5 \mathrm{mg} / \mathrm{L}$.

Site E manganese $(\mathrm{Mn})$ metal concentration is $76.5 \mathrm{mg} / \mathrm{L}$ in summer and ranged from $<23.9-99.3 \mathrm{mg} / \mathrm{L}$ in autumn, which all exceeded USEPA (2003) and RSA (1995) limit of $0.05 \mathrm{mg} / \mathrm{L}$ and WHO (2011) limit of $0.1 \mathrm{mg} / \mathrm{L}$. Iron (Fe) metal concentration in summer with $204.2 \mathrm{mg} / \mathrm{L}$ and ranged from $<23.9-652.8 \mathrm{mg} / \mathrm{L}$ in autumn, which were all exceeded the RSA (1995) limit of $0.1 \mathrm{mg} / \mathrm{L}$. Nickel (Ni) in summer is $14.3 \mathrm{mg} / \mathrm{L}$ and ranged from $<0.04-8.9 \mathrm{mg} / \mathrm{L}$ in autumn, which were all exceeded USEPA (2003) and WHO (2011) limits of $0.07 \mathrm{mg} / \mathrm{L}$ and RSA (1995) limit of $0.02 \mathrm{mg} / \mathrm{L}$. Copper $(\mathrm{Cu})$ metal concentration is $6.1 \mathrm{mg} / \mathrm{L}$ in summer and ranged from $<0.20-20 \mathrm{mg} / \mathrm{L}$ in autumn, which were all exceeded the limits of WHO (2011) of $0.05 \mathrm{mg} / \mathrm{L}$, USEPA of $0.003 \mathrm{mg} / \mathrm{L}$ and RSA (1995) of $5 \mathrm{mg} / \mathrm{L}$. Chromium (Cr) metal concentration is $4.7 \mathrm{mg} / \mathrm{L}$ in summer and ranged from $<0.01-2.6 \mathrm{mg} / \mathrm{L}$ in autumn, which exceeded the limits of WHO (2011) of $0.05 \mathrm{mg} / \mathrm{L}$, USEPA (2003) of $0.003 \mathrm{mg} / \mathrm{L}$ and RSA (1995) limit of $5 \mathrm{mg} / \mathrm{L}$. Cadmium (Cd) metal concentration is $1.1 \mathrm{mg} / \mathrm{L}$ in summer and ranged from $<0.06-17.7 \mathrm{mg} / \mathrm{L}$ in autumn, which were all exceeded USEPA (2003) and WHO(2011) of $0.03 \mathrm{mg} / \mathrm{L}$ and below RSA (1995) limit of $5 \mathrm{mg} / \mathrm{L}$. Lead (Pb) metal concentration is $1204.7 \mathrm{mg} / \mathrm{L}$ in summer and ranged from $7.9-15.7 \mathrm{mg} / \mathrm{L}$ in autumn exceeded USEPA (2003) limit of $0.05 \mathrm{mg} / \mathrm{L}$ and WHO (2011) limit of $0.01 \mathrm{mg} / \mathrm{L}$.

Comparing the study results with research done by (Moja and Mnisi [12]) the essential metals concentration for $\mathrm{Mn}$ ranged from $5.06-10.23 \mathrm{mg} / \mathrm{L}$ whereas for the study results ranged from $<0.5-99.3 \mathrm{mg} / \mathrm{L}$ both in autumn and ranged from $2.5-4.31 \mathrm{mg} / \mathrm{L}$ the study results ranged from $<0.5-76.5 \mathrm{mg} / \mathrm{l}$ both in summer, which were all exceeded WHO (2011) limit of $0.1 \mathrm{mg} / \mathrm{L}$, USEPA (2003) and RSA (1995) limits of $0.05 \mathrm{mg} / \mathrm{L}$. Iron (Fe) metal concentration ranged from $2.45-8.56 \mathrm{mg} / \mathrm{L}$ comparing with the results $<23.9-297.4 \mathrm{mg} / \mathrm{L}$ both in autumn and ranged from $2.3-7.23 \mathrm{mg} / \mathrm{L}$ comparing with the study results ranged from $<23.9-204.2 \mathrm{mg} / \mathrm{L}$ both in summer comparing with the results which were all exceeded RSA (1995) limit of $0.1 \mathrm{mg} / \mathrm{L}$. Nickel (Ni) ranged from 1.2-3.45 mg/L comparing with the study results ranged from $<0.04-34.1 \mathrm{mg} / \mathrm{L}$ both in autumn and $0.14-3.54 \mathrm{mg} / \mathrm{L}$ in summer comparing with the study results ranged from $<0.04-14.3 \mathrm{mg} / \mathrm{L}$ both in Autumn, which all exceeded WHO (2011), USEPA (2003) limits of $0.07 \mathrm{mg} / \mathrm{L}$ and RSA (1995) limit of $0.02 \mathrm{mg} / \mathrm{L}$. Copper $(\mathrm{Cu})$ ranged from $1.01-2.57 \mathrm{mg} / \mathrm{L}$ comparing with the study results ranged from $<0.20-3.3 \mathrm{mg} / \mathrm{L}$ both in autumn and ranged from $0.1-2.26 \mathrm{mg} / \mathrm{L}$ comparing with 
the study results ranged from $<0.20-6.1 \mathrm{mg} / \mathrm{L}$ both in summer, which exceeded RSA (1995) limit of $1 \mathrm{mg} / \mathrm{L}$.

\subsection{SEM-EDS results}

The results confirm the presence of chrysotile $\left(\mathrm{Mg}_{3}\left(\mathrm{Si}_{2} \mathrm{O}_{5}\right)(\mathrm{OH})_{4}\right)$ of the serpentine $\left(\mathrm{Mg}_{3}(\mathrm{OH})_{4}\left(\mathrm{Si}_{3} \mathrm{O}_{5}\right)\right)$ group and amphibole $\left(\mathrm{NaCa}_{2}(\mathrm{Mg}, \mathrm{Fe}, \mathrm{Al})_{5}(\mathrm{Al}, \mathrm{Si})_{8} \mathrm{O}_{22}(\mathrm{OH})_{2}\right)$ mineral group and other silicate minerals is quartz $\left(\mathrm{SiO}_{2}\right)$, mica $\left(\mathrm{KAI}_{2}\left(\mathrm{Si}_{3} \mathrm{AlO}_{10}\right)(\mathrm{OH})_{2}\right)$, and plagioclase $\left(\mathrm{NaAlSi}_{3} \mathrm{O}\right)$. The non-silicate mineral detected was kaolinite $\left(\mathrm{Al}_{2} \mathrm{Si}_{2} \mathrm{O}_{5}(\mathrm{OH})_{4}\right)$, feldspar $\left(\mathrm{KAISQ}_{3} \mathrm{O}_{8}\right)$ and chlorite $\left((\mathrm{Mg}, \mathrm{Fe})_{3}(\mathrm{Si}, \mathrm{Al})_{4} \mathrm{O}_{10}\right)$. At site $\mathrm{A}$ and site $\mathrm{B}$ the size particles is $100 \mu \mathrm{m}$ for semi-rectangular and the shape characterized by straw or bundle clustered together and also organic fiber detected. The size particles measured ranged from $300 \mu \mathrm{m}$ to $400 \mu \mathrm{m}$ for semi-rectangular and the shape characterized by bundle clustered together for Site D. According to the research reported by (Harris et al. [13]) determining of mixed mineral dust particles and characterizing particles confirms the presences of the following the minerals amphibole using field emission scanning electron microscopy (FESEM). FESEM indicated the morphology features such as shape fiber-like cleavage fragments which are presence from the mixed mineral dust samples. The fibers were thin particles with width $<0.05 \mu \mathrm{m}$ with parallel side smooth surface and ratios detected 20:1 to 100:10 or even higher and often displayed on curvature. Include the results on SEM-EDS results detected not of sites $\mathrm{C}$ and $\mathrm{E}$.

\section{CONCLUSIONS}

All of the dust-fall rates exceeded the residential limit of $600 \mathrm{mg} / \mathrm{m}^{2} /$ day at all the five sites. All the essential and non-essential metal concentration exceeded the local and

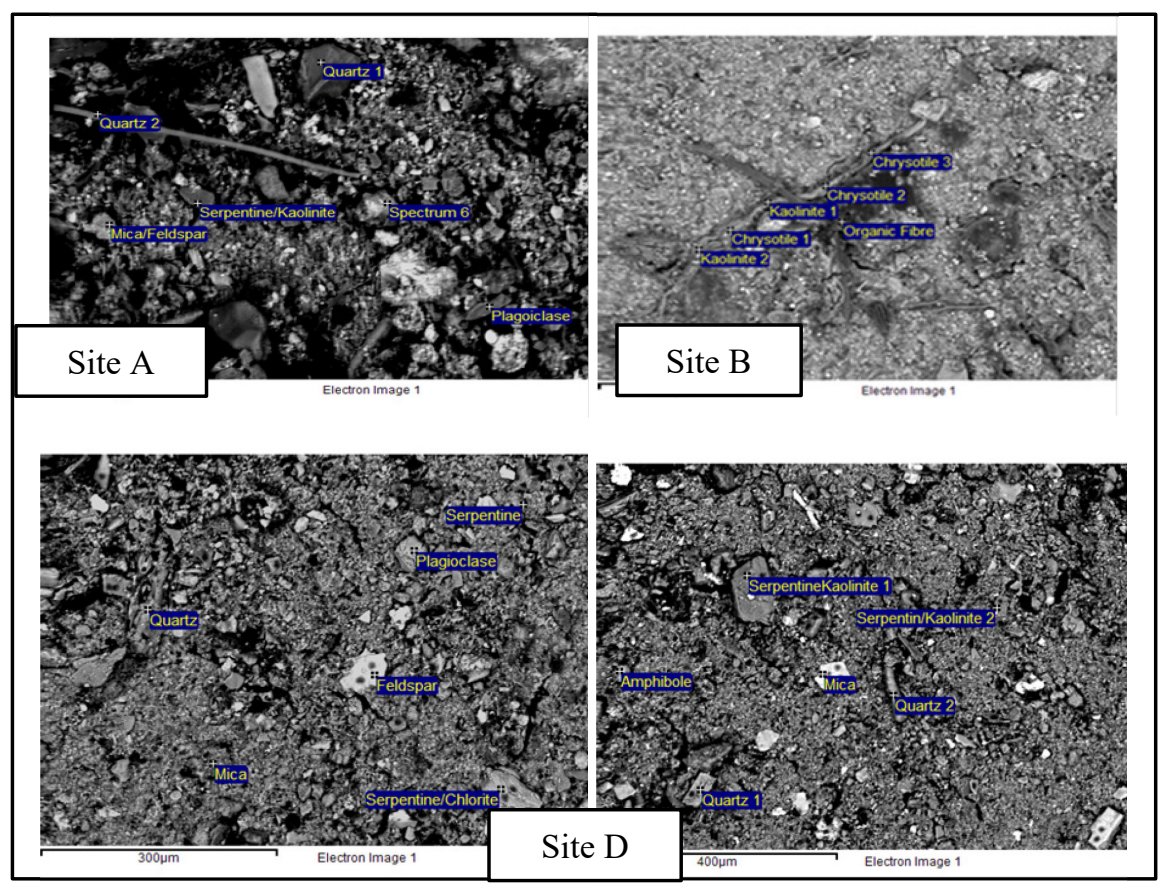

Figure 5: SEM-EDS results. 
international limits/standards for all the sites except for Chromium $(\mathrm{Cr})$ which it is below RSA (1995) limit of $5 \mathrm{mg} / \mathrm{L}$. The SEM-EDS results confirm the presence of chrysotile $\left(\mathrm{Mg}_{3}\left(\mathrm{Si}_{2} \mathrm{O}_{5}\right)(\mathrm{OH})_{4}\right)$ of the serpentine $\left(\mathrm{Mg}(\mathrm{OH}) 4\left(\mathrm{Si}_{3} \mathrm{O}_{5}\right)\right)$ group and amphibole $\left(\mathrm{NaCa}_{2}(\mathrm{Mg}, \mathrm{Fe}, \mathrm{Al})_{5}(\mathrm{Al}, \mathrm{Si})(\mathrm{OH})_{2}\right)$ minerals groups. The other silicate minerals detected were quartz $\left(\mathrm{SiO}_{2}\right)$, plagioclase $\left(\mathrm{NaAlSi}_{3} \mathrm{O}\right)$, kaolinite $\left(\mathrm{Al}_{2} \mathrm{Si}_{2} \mathrm{O}_{2}(\mathrm{OH})_{4} \mathrm{MgFe}^{++5} \mathrm{Al}\left(\mathrm{Si}_{2} \mathrm{Al}\right) \mathrm{O}_{10}(\mathrm{OH})\right)$, feldspar $\left(\mathrm{KAISQ}_{3} \mathrm{O}_{8}\right)$ and mica $\left.\left(\mathrm{KAI}_{2} \mathrm{Si}_{2} \mathrm{Al}_{10}\right)(\mathrm{OH})_{2}\right)$. The data will be used to motivate for the acceleration of the rehabilitation of the non-rehabilitated mine dumps. Rehabilitation process should involve vegetation, back filling and sealing of shafts. This approach will go a long way in reducing the physical safety of unstable sloped and reducing possible airborne asbestos dust or fibers.

\section{ACKNOWLEDGEMENTS}

The author would like to thank the Air Quality team, Wet Chemistry and Mineralogy Laboratories for their analysis of the samples, and Sihle Sogayise for creating the maps.

\section{REFERENCES}

[1] Hart, H.P., Asbestos in South Africa. Journal of South Africa Institute Mining, 8(6), pp. 185-198, 1988.

[2] Muculloch, J., Surviving blue asbestos: Mining and occupational diseases in South Africa and Australia. ISSN 0258-7696 Transformation, p. 65, 2007.

[3] Abratt, R., Vorobiof, D. \& White, N. Asbestos and Mesothelioma in South Africa, Science Direct. 2002. http://www.sciencedirect.com/science/article/pii/S0169500 $\underline{204001631}$

[4] Felix, M.A., Leger, J.P. \& Ehrlich, R.J., Three minerals, three epidemics-Asbestos mining and diseases in South Africa, pp. 265-285, 1998.

[5] Ehlers, D.L. \& Vorster, C.J., Asbestos, pp. 68-75. The Mineral Resources of South Africa, Handbook Council for Geosciences 16, eds M.G.C Wilson \& C.R. Anhaeusser, p. 740, 1998.

[6] Perkins, R.L. \& Harvey, B.W., U.S. Environmental Protection Agency, Test Method for the Determination of Asbestos in Bulk Building Materials, EPA/600/R-93/116, 1993.

[7] Atanasova, M., The Scanning Electron Microscopy Mineralogy Laboratory Method, Council for Geosciences, 2016.

[8] NDCR (National Dust Control Regulations) 827, Dust fall, 1 Nov. 2013.

[9] Republic of South Africa (RSA), Water Quality Guidelines for Industrial Use, No. 3, Department of Water Affairs and Forestry, 2nd ed., 1995.

[10] United States Environmental Protection Agency (USEPA), Water Quality Standards for Domestic Use, 2003.

[11] World Health Organization (WHO), Water Quality Guidelines for Industrial Use, 2011.

[12] Moja, S.J. \& Mnisi, J.S., Seasonal variations in airborne heavy metals in Vanderbijlpark, South Africa. Journal of Environmental Chemistry and Ecotoxicology, 5(9), pp. 227-233. DOI: 10.5897/JECE2013.029, 2013.

[13] Harris, K.E., Bunker, K.L., Strohmeier, H.R. \& Lee, R.J., Discovering the true morphology of amphibole minerals: Complementary TEM and FESEM characterization of particles in mixed mineral dust. Modern Research and Educational Topics in Microscopy, eds A. Mendez-Vilas \& J. Diaz, 2007. 